\title{
The Potential Contamination of the Groundwater Resources in the Vicinity of Al-Ekeder Disposal Site, North Jordan
}

\author{
Majdi Majdalawi ${ }^{1}$, Omar Rimawi ${ }^{2}$, Ziad Abu-Hamatteh ${ }^{3}$, Ali El-Naqa ${ }^{4} \&$ Nafeth Abdel Hadi $^{3}$ \\ ${ }^{1}$ Zarqa University College, Al-Balqa' Applied University, Jordan \\ ${ }^{2}$ University of Jordan, Faculty of Science, Dept. of Applied and Environmental Geology, Jordan \\ ${ }^{3}$ Faculty of Engineering Technology, Al-Balqa' Applied University, Jordan \\ ${ }^{4}$ Faculty of Natural Resources, The Hashemite University, Jordan \\ Correspondence: Majdi Majdalawi, Zarka University College, Al-Balqa’ Applied University, Zarka, Jordan. Tel: \\ 962-777-731-7446. E-mail: majdalawi@chemist.com
}

Received: July 1, 2013 Accepted: August 2, 2013 Online Published: September 11, 2013

doi:10.5539/ijc.v5n4p27

URL: http://dx.doi.org/10.5539/ijc.v5n4p27

\begin{abstract}
Al-Ekeder landfill leachate constitutes represent a serious threat to the local aquifers. Al-Ekeder Disposal Site (ADS) is the only official dumpsite for northern Jordan, serving 62 towns and villages, and considered as the second largest landfill in Jordan. The major concern at ADS is the potential contamination of groundwater extracted by private wells for irrigation and drinking purposes and located adjacent to the Disposal Site. The current study represents a preliminary understanding of the problems and issues of the Al-Ekeder hydrogeological conditions. Groundwater samples from the productive wells in the surroundings of ADS have been collected and analysed for chemical and biological parameters. Generally, some changes are observed in some groundwater samples particularly in the western wells. Consequently, and in order to compare theses results, leachate and septage samples were collected and analyzed for chemical and biological parameters. The analyses of the leachate samples indicate, as expected, high values for both BOD (2,525 mg/l) and COD $(168,000 \mathrm{mg} / \mathrm{l})$ with heavy metals concentrations such as, mercury, lead, cadmium and arsenic were found to be $15.7 \mu \mathrm{g} / \mathrm{l}, 5.5 \mu \mathrm{g} / \mathrm{l}, 12.2 \mu \mathrm{g} / \mathrm{l}$, and $2.5 \mu \mathrm{g} / \mathrm{l}$, respectively. The analyses of septage samples indicate that the EC values range between $5450 \mu \mathrm{S} / \mathrm{cm}$ and $5800 \mu \mathrm{S} / \mathrm{cm}$. The concentrations of heavy metals mercury, lead, cadmium and arsenic are ranging (0.5 to 2.2$) \mu \mathrm{g} / \mathrm{l},(110$ to 190$) \mu \mathrm{g} / \mathrm{l},(5$ to 14$) \mu \mathrm{g} / \mathrm{l}$, and (0 to 0.55$) \mu \mathrm{g} / \mathrm{l}$, respectively. The water quality of the groundwater resources at the western side of ADS shows small changes in the EC/TDS values and in some hydrochemical parameters such as, $\mathrm{NO}_{3}$, which is attributed to the nitrification processes of the infiltrated water from the septage in ADS. However, no serious increases in the heavy metals were reported and this is attributed to the heavy metal precipitation processes within the chack limestone of $\mathrm{B}_{3}$ during the infiltration processes.
\end{abstract}

Keywords: water resources, contamination, waste, landfill, Al-Ekeder, Jordan

\section{Introduction}

The landfill is the most common technology used to dispose the municipal solid residues, particularly in developing countries. It consists of series of deposition cells after being reduced to the minimum volume using compaction techniques (Olivero-Verbel, Padilla-Bottet, \& LaRosa, 2008). Large quantities of wastes from urban, municipal and industrial sectors are generated worldwide end up in the surrounding environment, with little or no treatment. Uncontrolled landfill acts lead to serious threatens to groundwater and surface water resources (Futta, Yoscos, Haralambous, \& Loizidou, 1997). Groundwater contamination may occur through infiltration from surface water, direct migration and inter-aquifer exchange. Generally, these processes are responsible for contamination of the surface and groundwater resources (Abu-Rukah \& Al-Kofahi, 2001).

Several studies conducted on the operation of Al-Ekeder Disposal Site (ADS). Abu-Rukah and Al-Kofahi (2001) indicated that Al-Ekeder landfill leachates constitute represent a serious threat to the local aquifers. Awawdeh and Jaradat (2009), based on an evaluation of aquifer vulnerability to contamination in the Yarmouk River Basin, demonstrated that the dominance of low vulnerability classes, except for limited areas, which have moderate vulnerabilities distributed in the southwest and north of the study area. ADS commenced its operation in 1980, 
since then, several studies were conducted investigating the design, environmental impact assessments, improvements and upgrading various types of wastes, recommending actions to improve the operational management of the disposal site.

The study area is located in the Northern part of Jordan, within the local boundaries of Irbid and Mafraq Governorates (Figure 1). It is located $27 \mathrm{~km}$ to the east of the Irbid city, adjacent to the Syrian border. Valley Al-Ekeder flows from the disposal area northwest towards the Syrian border (about $2 \mathrm{~km}$ ) and the city of Dera'a. Al-Ekeder is the only legal location for the disposal of liquid waste in the entire study area.

Generally, ADS is the only official dumpsite for northern Jordan, serving 62 towns and villages, and considered as the second largest landfill in Jordan. In addition to the municipal solid and seasonal wastes from olive mill operations, the landfill receives large volume of liquid wastewaters from textile enterprises. The liquid waste is released from the tanks of the transport trucks into an open pond above the valley and from there through further settling and evaporation ponds into the valley. Part of the water is used to irrigate trees.

All waste streams are disposed in specially constructed unlined ponds. Eight ponds are currently used for wastewater, and the rest for solid waste disposal. The site is located within a natural valley with an approximate gradient of 2-3\% slopping EW and NW. After leaving the site, the valley turns towards the north, enters Syria and eventually meets the Yarmouk River. The nature of soil in the site is silty to silty-sand The groundwater aquifer is confined and located at a depth of $350-450 \mathrm{~m}$ below the ground surface. The climate is mostly dry and hot in summer, and wet and cool in winter, with an average annual rainfall of 150-200 mm (Figure 2).

The major concern at ADS is the potential contamination of groundwater extracted by private wells for irrigation and drinking purposes and located adjacent to the Disposal Site. The Royal Scientific Society (The Royal Scientific Society [RSS], 2006) proved that some wells show contamination containing high values of turbidity, total dissolved solids, hardness, arsenic and total microbial contaminants, exceeding the maximum allowable limits compared to the National Drinking Water Standards (Jordan Standards [JS] 286, 2001).

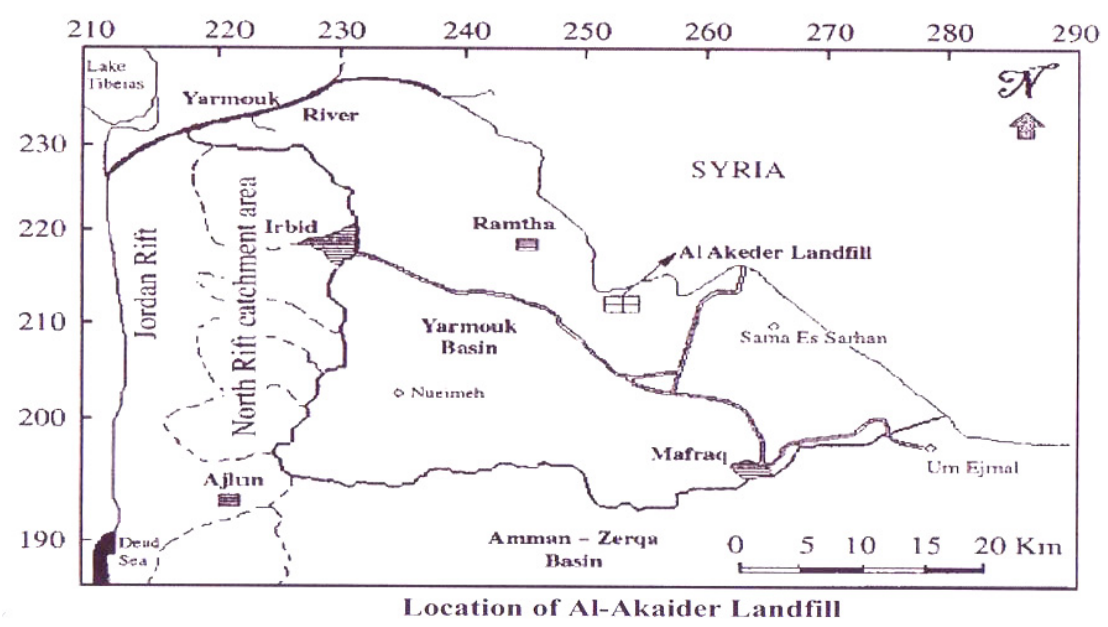

Figure 1. Location map of Al-Ekeder landfill

\section{General Geology}

A geological survey was conducted and confirmed through field visits using the earlier Natural Resources Authority geological maps and reports of the area under investigation. The exposures of sedimentary rocks belong to the Upper Cretaceous and Lower Tertiary comprises limestone, chert, chalk and marl. 


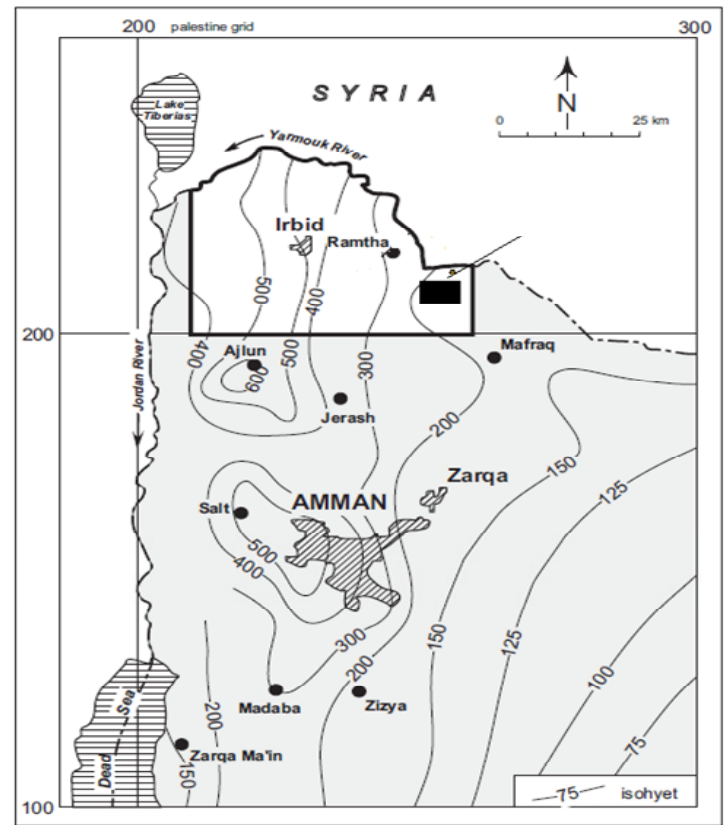

Figure 2. Long-term average rainfall in the study area ( $\mathrm{mm} / \mathrm{year})$

The sequence of the exposed geological formations in the area of ADS and the surrounding area is characterized by the presence of the following three main formations, i.e., Recent Deposits; Umm Rijam Formation $\left(\mathrm{B}_{4}\right)$ and Muwaqqar Formation $\left(\mathrm{B}_{3}\right)$ (Figure 3). These formations were identified in the previous studies carried out in regional geological and hydrogeological studies of Jordan (MacDonald \& Partners, 1969; Bender, 1968, 1974; UNDP/FAO, 1970; Khoury \& Salameh, 1985; El-Naser, 1991; Rimawi, 1992; Salameh, 1996; Swarieh \& Masarweh, 1997) and are identified by the current study during the field investigation in 2011. Generally, the sequence described in this text follows the nomenclature used by the Natural Resources Authority of Jordan Geological Mapping Division. The field survey revealed the following main lithological characteristics of the outcropping formations from top to bottom:

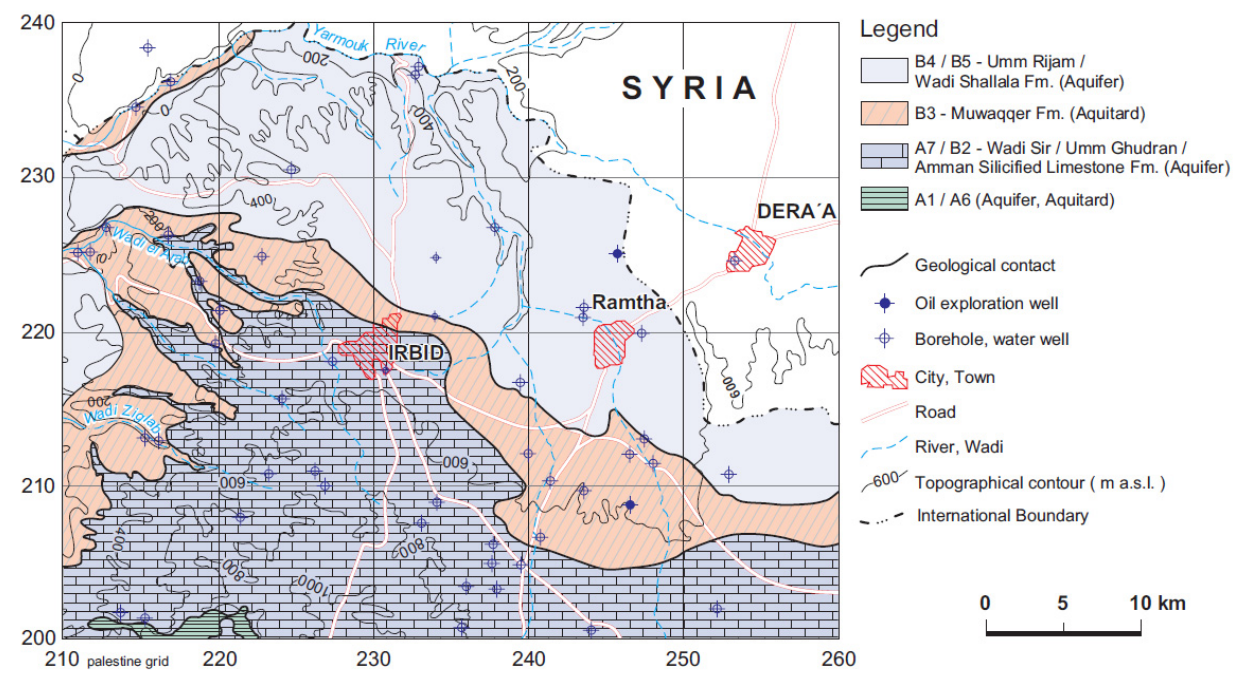

Figure 3. Surface distribution of the major geo-hydrogeological units in northwestern Jordan (Margaene, Hobler, \& Subah, 1999) 


\subsection{Recent Deposits}

These deposits occur in the form of alluvial deposits or consolidated gravels of chert and coarse limestone of small thickness. The gravels are mostly consolidated and covered by thin layer of soil. The thickness of the soil layer varies from few centimeters to more than $2 \mathrm{~m}$.

\subsection{Umm Rijam Formation $\left(B_{4}\right)$}

Umm Rijam Formation represents the uppermost part of the sedimentary rocks in the area. The exposed rocks in the disposal site found in isolated locations on the top of the hills without any clear relationship. The thickness of this formation at the ADS is ranging from $15-20 \mathrm{~m}$, possibly due to erosion activity in this area. It belongs to the Lower and Middle Eocene and overlies Muwaqqar Formation $\left(\mathrm{B}_{3}\right)$, which is exposed in the most of the disposal site. The exposed rocks of Umm Rijam Formation consisting of limestone, chalky limestone alternating with brown to black chert. The Muwaqqar Formation is considered as an aquifer in Jordan due to the alteranative nature of its constituents, e.g., Ramtha (Adjacent to ADS), Azraq and Jafer Basins. Yet, it cannot be considered as an aquifer in this area due to its small thickness and isolated nature.

\subsection{Muwaqqar Formation $\left(B_{3}\right)$}

Muwaqqar Formation $\left(\mathrm{B}_{3}\right)$ is the oldest exposed rock in the disposal site and it is of Maastrichtion-Paleocene age. According to MacDonald and Partners (1969), the estimated thickness of this formation near Al-Ekeder is about $320 \mathrm{~m}$ as endorsed by (Water Authority of Jordan \& Bundesanstalt fuer Geowissenschaften und Rohstoffe [WAJ/BGR], 1997). Lithologically, this formation is dominated by the presence of chalk, marl, and chalky limestone, thin beds of chert, phosphate, bituminous chalk and nodules and concretions of limestone. The major joint system in this formation is $120 \mathrm{NW} / 30 \mathrm{NE} / \mathrm{SW}$ with minor joints trending $100 \mathrm{NE} / \mathrm{SW}, 70 \mathrm{NW} / \mathrm{SE}$ and 170 NNW/SSE. Generally, the lithological descriptions of the above-mentioned formations are attributed to the outcropping rocks. The subsurface geology underlying Muwaqqar $\left(\mathrm{B}_{3}\right)$, Amman $\left(\mathrm{B}_{2}\right)$, Umm Ghudran $\left(\mathrm{B}_{1}\right)$, Wadi-As-Sir $\left(\mathrm{A}_{7}\right)$ and Shueib $\left(\mathrm{A}_{6} / \mathrm{A}_{5}\right)$ formations are described in the Hydrogeology section.

\section{Hydrogeology}

The current study represents a preliminary understanding of the problems and issues of the Al-Ekeder hydrogeological conditions. Several investigations conducted in the northern part of Jordan including some hydrological and hydrogeological studies (e.g., Khoury \& Salameh, 1985; El-Naser, 1991; Rimawi, 1992; Salameh, 1996; Swarieh \& Masarweh, 1997). In order to understand the hydrological conditions at the site, it necessary to describe the geology of the exposed formations at the surface and the subsurface lithology of the recovered samples from the drilled bore holes or water wells. The existing geological formations at ADS and the surrounding areas are mainly composed of sedimentary rocks, i.e., Rijam Formation $\left(\mathrm{B}_{4}\right)$, Muwaqqar Formation $\left(B_{3}\right)$, Amman Formation $\left(B_{2}\right)$, Umm Ghudran Formation $\left(B_{1}\right)$, Wadi-As-Sir Formation $\left(A_{7}\right)$, Shueib Formation $\left(\mathrm{A}_{5} / \mathrm{A}_{6}\right)$, and Hummar Formation $\left(\mathrm{A}_{4}\right)$.

The Rijam Formation $\left(\mathrm{B}_{4}\right)$ is considered as an aquifer at many places in Jordan; however, it is not categorized as an aquifer within ADS due to its isolated nature with very thin beds and limited thickness. The Muwaqqar Formation $\left(\mathrm{B}_{3}\right)$ represents the dominant exposed rocks in the area. It is composed of thick chalk and marl, and considered as an aquiclude due to its low vertical permeability. This formation confined of the underlying aquifer system of Amman/Wadi-As-Sir Formation $\left(\mathrm{B}_{2} / \mathrm{A}_{7}\right)$.

The Amman Formation $\left(B_{2}\right)$ and Wadi-As-Sir Formation $\left(A_{7}\right)$ which are geologically separated by small thickness of $\left(\mathrm{B}_{1}\right)$ Wadi Umm Ghudran Formation. They are considered as the main composite aquifers in the area. The underling Shueib Formation $\left(\mathrm{A}_{5 / 6}\right)$ is considered an aquiclude.

The chalk and marl forming Muwaqqar Formation and the lower member of the Wadi Umm Ghudran Formation show low permeability depending on the jointing and fracturing of the chalky limestone. Amman Formation $\left(\mathrm{B}_{2}\right)$ which is mainly composed of alternating beds of chert and limestone, are of highly permeability nature due to jointing and fracturing and cavities, between the chert and limestone. On the other hand, Wadi-As-Sir Formation is mostly jointed, fractured and partially karstified is consider of high permeability too.

The main aquifer of the Jordanian Highlands is moderately to highly fractured and moderately karstified $A_{7} / B_{2}$ (limestone) with a total thickness of 300-500 m (Figure 4). In the western and northern directions, the $\mathrm{A}_{7} / \mathrm{B}_{2}$ aquifer is covered by the predominantly Muwaqqar Formation $\left(\mathrm{B}_{3}\right)$ aquitard with a thickness increasing from some $100 \mathrm{~m}$ in the east to more than $500 \mathrm{~m}$ towards the North and North East. Moreover, in the northern part of the study area, the limestone and the chert limestone $\left(\mathrm{B}_{4} / \mathrm{B}_{5}\right)$ Formations constitute the upper most unconfined aquifer overlying the $B_{3}$ aquitard (Figure 4$)$. Generally, the $\left(B_{2} / A_{7}\right)$ Aquifer System represents the main aquifer confined system in the area where it is located between $\left(B_{3}\right.$ and $\left.A_{5 / 6}\right)$ aquitard (Figure 4). 


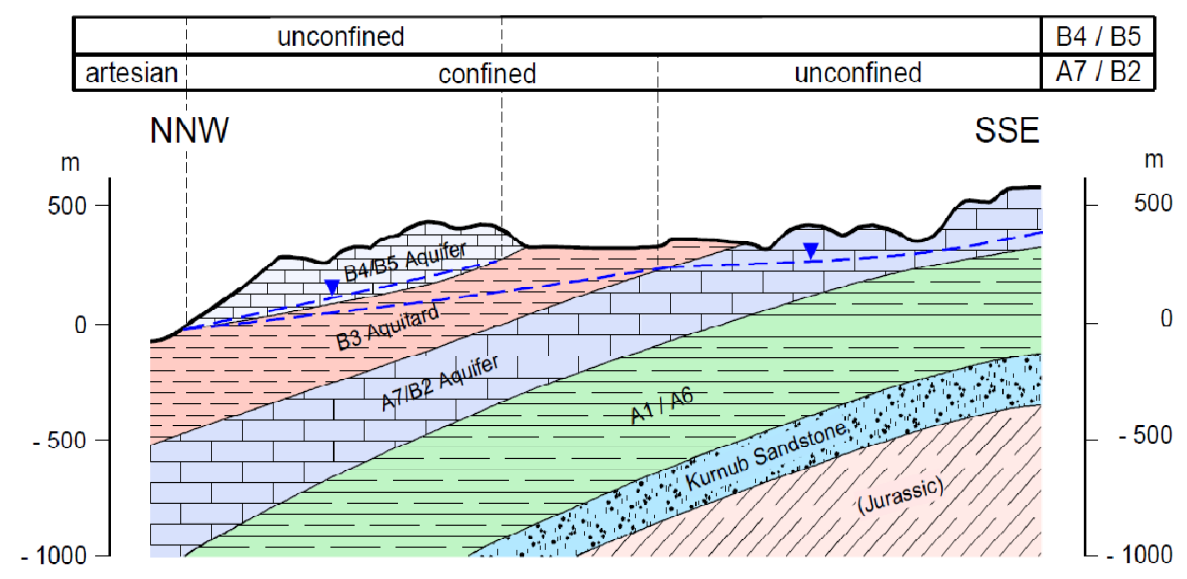

Figure 4. Schematic hydrogeological cross section through the study area (Margaene et al., 1999)

Figure (5) shows the groundwater piezometric map of the $\left(B_{2} / A_{7}\right)$ Aquifer System, as constructed from the drilled groundwater wells in the surrounding of ADS (Margaene et al., 1999). The spatial distribution of the groundwater wells in the vicinity of Al-Ekeder landfill, the distribution and the hydraulic characteristics of the aquifers are represented in Figure (6). The groundwater flow direction beneath the ADS is from east to west as indicated in Figure (5). The piezometric head of the groundwater under the ADS is about $400 \mathrm{~m}$ above sea level or about $100 \mathrm{~m}$ above the base of $\mathrm{B}_{3}$ aquitard. Generally, the depth of most of groundwater wells drilled in area exceeds $500 \mathrm{~m}$ penetrating the main aquifer $\left(\mathrm{B}_{2} / \mathrm{A}_{7}\right)$ Formations.

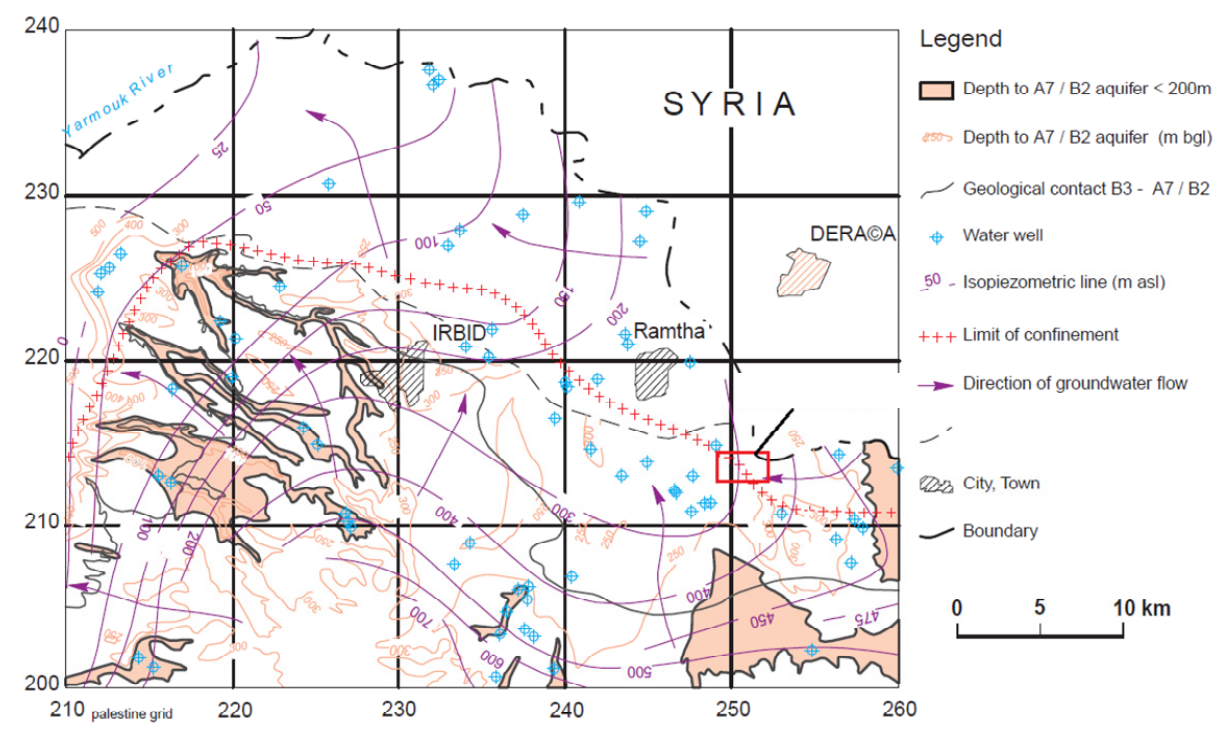

Figure 5. Regional groundwater flow pattern in $\mathrm{B}_{2} / \mathrm{A}_{7}$ Aquifer system (Margaene et al., 1999) 


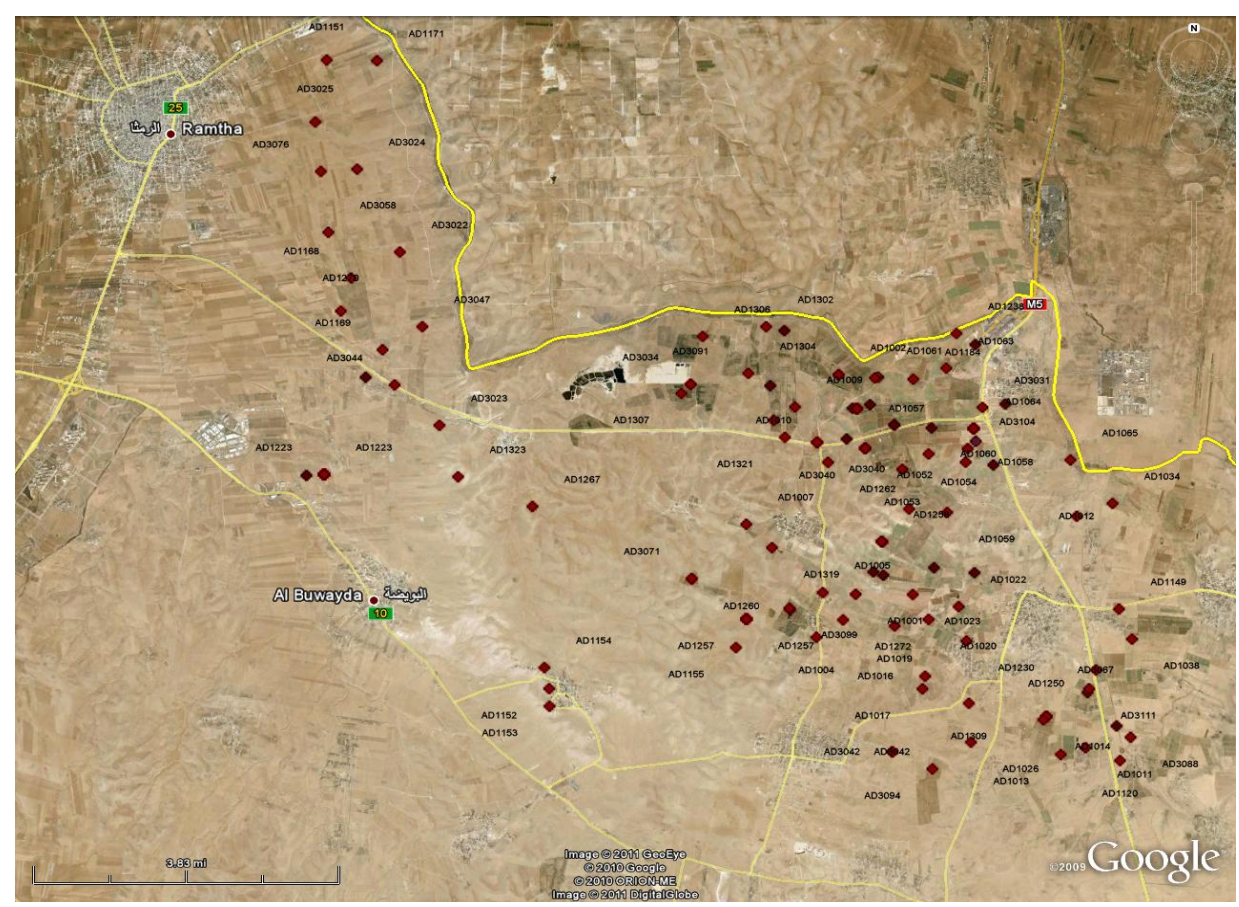

Figure 6. Spatial distribution of groundwater wells drilled in the vicinity of Al-Ekeder landfill

The vertical permeability of the $B_{3}$ Formation is relatively very low, showing a value of about $1 \times 10^{-9} \mathrm{~m} / \mathrm{s}$, as indicated in many studies (Bundesanstalt fuer Geowissenschaften und Rohstoffe BGR, 1987; WAJ/BGR, 1997). However, his value may increase due to the presence of major geological structures. In the normal condition, it will be extremely difficult for pollutants to seep and/or leach from the ADS to contaminate the groundwater body in the area. Yet, monitoring wells are highly recommended particularly, downstream of the ADS, as the possibility of contamination remains vital due the major geological structures related to the Jordan Rift Valley. The main purpose of these wells is to indicate any possible lateral/vertical movements of the wastewater from the ponds.

\section{Materials and Methods}

The degree of contamination and the water quality can be determined by sampling, testing and analyzing the quality of the superficial soil, septage, leachate, surface water and groundwater (Ball \& Novella, 2003). Investigating the subsurface materials of the disposal site by excavation of test pits and performing field percolation tests or drilling bore holes and conducting permeability testing in addition to water sampling.

Water quality shall be assessed by monitoring the existing water wells in the vicinity of Al-Ekeder site by collecting data from the concerned authorities and evaluating the results. However, in the downstream area of the groundwater flow, a new monitoring well should be drilled taking into consideration that the first aquifer encountered is the $\mathrm{B}_{2} / \mathrm{A}_{7}$ (Amman Formation and Wadi-As-Sir Formation) which is located at a depth more than $300 \mathrm{~m}$ from the ground surface. Caution, should be taken to avoid any leakage from the landfill pollutants and surface waste into this new well.

Generally, the ADS authority in order to control the quality of the surface water in the area and to avoid downstream transportation of pollutants from the disposal site, they constructed ponds downstream of the septage ponds to the temporary store of rainwater and excess of septage water. Since the quality of the surface water is controlled, the main objective of the current investigation is limited to evaluate the degree of contamination and the quality of the groundwater in the Eastern and Western parts of the landfill site. Based on the earlier studies, the collected water samples indicted no actual variation in the hydrochemical and biological parameters between the western and the eastern groundwater wells (Khoury \& Salameh, 1985; El-Naser, 1991; Rimawi, 1992; Salameh, 1996; Swarieh \& Masarweh, 1997; Rajkumar, Subramani, \& Elango 2012). Meanwhile, a potential contamination of the groundwater wells located within the vicinity of the landfill has been proved (Ministry of Environment, 2006). On the other hand, RSS (2006) verified the obtained results from some wells and indicated that they contained higher levels in some parameters, such as, turbidity, TDS, hardness, arsenic 
and total microbial contaminants as some of these values exceed the maximum allowable limits of the Jordanian Drinking Water Standards (JS 286/2001). Due to this and in order to emphasis the possible contamination of the groundwater resources in the area, new campaign of groundwater samples from the productive wells in the surroundings of ADS were ollected and analyzed for chemical and biological parameters, using the techniques of analyses adopted by the standard methods for the examination of water and wastewater (American Public Health Association, American Water Works Association, \& Water Environment Federation, 2005) (Table 1). Generally, some changes are observed in some groundwater samples particularly in the western wells. Consequently, and in order to compare theses results, leachate and septage samples were collected and analyzed for chemical and biological parameters (Table 2). The analyses of the leachate samples indicate, as expected, high values for both Biological Oxygen Demand (BOD: 2,525 mg/l) and Chemical Oxygen Demand (COD: 168,000 mg/l). The pH is almost neutral at 6.8 and the concentrations of heavy metals mercury, lead, cadmium and arsenic were found to be $15.7 \mu \mathrm{g} / \mathrm{l}, 5.5 \mu \mathrm{g} / \mathrm{l}, 12.2 \mu \mathrm{g} / \mathrm{l}$, and $2.5 \mu \mathrm{g} / \mathrm{l}$, respectively. The analyses of septage samples indicate that the Electrical Conductivity (EC) values range between $5450 \mu \mathrm{S} / \mathrm{cm}$ and $5800 \mu \mathrm{S} / \mathrm{cm}$ and the pH value is about 6.5. There is relatively little variation in the BOD and COD values. At the first pond where tankers discharge directly, the BOD is $472 \mathrm{mg} / \mathrm{l}$ and the COD is about $2000 \mathrm{mg} / \mathrm{l}$. Two representative samples were collected directly from the tankers (St IV, V) which show BOD of 620 and $548 \mathrm{mg} / \mathrm{l}$ and COD of 1810 and $1610 \mathrm{mg} / \mathrm{l}$.

The concentrations of heavy metals mercury, lead, cadmium and arsenic are ranging ( 0.5 to 2.2$) \mu \mathrm{g} / \mathrm{l}$, (110 to 190) $\mu \mathrm{g} / \mathrm{l}$, (5 to 14) $\mu \mathrm{g} / \mathrm{l}$, and ( 0 to 0.55$) \mu \mathrm{g} / \mathrm{l}$, respectively. In the downstream of the landfill site, various ponds had been constructed to prevent any overflow from the septage ponds reaching the Syrian border. Water in one of these ponds was collected and the analyses show a BOD of $136 \mathrm{mg} / \mathrm{l}$, COD of $1720 \mathrm{mg} / \mathrm{l}$ and Total Dissolved Solids (TDS) of $5025 \mathrm{mg} / \mathrm{l}$. The water quality of the groundwater resources at the western side of ADS shows small changes in the EC/TDS values and in some hydrochemical parameters such as nitrate which is attributed to the nitrification processes of the infiltrated water from the septage in ADS. But, no serious increases in the heavy metals have been reported and this is attributed to the heavy metal precipitation processes within the chack limestone of $\mathrm{B}_{3}$ during the infiltration processes. 
Table 1. Average results of physical, chemical and biological tests for water wells at the vicinity of Ekeder disposal site

\begin{tabular}{|c|c|c|c|c|c|c|c|c|c|c|}
\hline \multirow{2}{*}{$\begin{array}{l}\text { Para- } \\
\text { meter }\end{array}$} & \multirow[t]{2}{*}{ Unit } & \multicolumn{7}{|c|}{ Chemical and Biological Tests for Water Wells at the Vicinity of Al-Ekeder Disposal Site } & \multirow[b]{2}{*}{$\begin{array}{c}\text { Jordan } \\
\text { Drinking } \\
\text { Water } \\
\text { Specs. } \\
\text { No. } \\
(2008 / 28 \\
6)\end{array}$} & \multirow{2}{*}{$\begin{array}{c}\text { FAO } \\
\text { Instruc- } \\
\text { tions }\end{array}$} \\
\hline & & $\begin{array}{c}\text { Farhan } \\
\text { Well (1) }\end{array}$ & $\begin{array}{l}\text { Swelmieh } \\
\text { Well (1) }\end{array}$ & $\begin{array}{c}\mathrm{AD} 1320 \\
(1)\end{array}$ & $\begin{array}{l}\text { Al-Ghazza } \\
\text { wi Well (6) }\end{array}$ & $\begin{array}{l}\text { Al-Tabba } \\
\text { 'a Well } \\
(6)\end{array}$ & $\begin{array}{c}\text { Abu } \\
\text { Kushuk } \\
\text { Well (5) }\end{array}$ & $\begin{array}{c}\text { WAJ } \\
\text { Well (2) }\end{array}$ & & \\
\hline $\mathrm{pH}$ & SU & 7.98 & 8 & 7.54 & 7.5 & 7.1 & 7.5 & 7.7 & $6.5-8.5$ & $6.5-8.4$ \\
\hline COD & $\mathrm{mg} / \mathrm{L}$ & 5.8 & 6.7 & 7 & 7.8 & 9 & 8.4 & $\ldots$ & $\ldots$ & $\ldots$ \\
\hline EC & $\mu \mathrm{S} / \mathrm{cm}$ & 841 & 833 & 836 & 910 & 1049 & 940 & 735 & $\ldots$ & $\begin{array}{l}700-300 \\
0\end{array}$ \\
\hline TDS & $\mathrm{mg} / \mathrm{L}$ & 492 & 482 & 540 & 507 & 548 & 588 & 405 & 1000 & $\begin{array}{l}450-200 \\
0\end{array}$ \\
\hline Turbidity & NTU & 0.18 & 6.35 & 1.85 & 5.0 & 2.9 & 9.9 & 22.7 & 5 & $\ldots$ \\
\hline Color & PCU & $\ldots$ & $\ldots$ & $\ldots$ & $<5$ & $<5$ & $<5$ & $<5$ & 15 & $\ldots$ \\
\hline $\mathrm{SO}_{4}$ & $\mathrm{mg} / \mathrm{L}$ & 34.4 & 32.1 & 34.2 & 38.6 & 85.9 & 50.8 & 44.5 & 500 & $\ldots$ \\
\hline $\mathrm{Cl}$ & $\mathrm{mg} / \mathrm{L}$ & 110 & 98 & 105 & 118 & 100 & 114 & 82 & 500 & $\ldots$ \\
\hline $\mathrm{Na}$ & $\mathrm{mg} / \mathrm{L}$ & 78 & 68 & 71 & 62 & 62 & 57 & 56 & 200 & $\ldots$ \\
\hline $\mathrm{Mg}$ & $\mathrm{mg} / \mathrm{L}$ & 29 & 31 & 25 & 32 & 39 & 33 & 31 & $\cdots$ & $\ldots$ \\
\hline $\mathrm{Ca}$ & $\mathrm{mg} / \mathrm{L}$ & 55 & 58 & 63 & 75 & 105 & 87 & 50 & $\ldots$ & $\ldots$ \\
\hline SAR & & $\ldots$ & $\ldots$ & $\ldots$ & 1.49 & 1.30 & 1.31 & 1.50 & $3-9$ & $\ldots$ \\
\hline $\mathrm{NO}_{3}$ & $\mathrm{mg} / \mathrm{L}$ & $<0.1$ & $<0.1$ & $<0.1$ & $<0.1$ & 0.55 & 1.46 & 2.30 & 50 & $22-133$ \\
\hline TOC & $\mathrm{mg} / \mathrm{L}$ & $\ldots$ & $\ldots$ & $\ldots$ & 2.89 & 2.03 & 3.77 & $<1.6$ & $\ldots$ & $\ldots$ \\
\hline $\begin{array}{c}\mathrm{TH} \text { as } \\
\left(\mathrm{CaCO}_{3}\right)\end{array}$ & $\mathrm{mg} / \mathrm{L}$ & 258 & 271 & 261 & 321 & 423 & 349 & 254 & 500 & $\ldots$ \\
\hline TKN & $\mathrm{mg} / \mathrm{L}$ & $<4.5$ & $<4.5$ & $<4.5$ & $<4.5$ & $<4.5$ & $<4.5$ & $<4.5$ & $\ldots$ & $\ldots$ \\
\hline $\begin{array}{c}\text { Alkalinit } \\
\mathrm{y}\end{array}$ & $\mathrm{mg} / \mathrm{L}$ & $\ldots$ & $\ldots$ & $\ldots$ & 267 & 313 & 257 & 207 & $\cdots$ & $\cdots$ \\
\hline B & $\mathrm{mg} / \mathrm{L}$ & 0.11 & $<0.1$ & $<0.1$ & 0.166 & 0.193 & 0.128 & 0.120 & 1 & $0.7-3$ \\
\hline $\mathrm{Ag}$ & $\mathrm{mg} / \mathrm{L}$ & $<0.01$ & $<0.01$ & $<0.01$ & $<0.1$ & $<0.1$ & $<0.1$ & $<0.1$ & 0.1 & $\ldots$ \\
\hline $\mathrm{Al}$ & $\mathrm{mg} / \mathrm{L}$ & $\ldots$ & $\ldots$ & $\ldots$ & $<0.7$ & $<0.7$ & $<0.7$ & $<0.7$ & 0.1 & 5 \\
\hline $\mathrm{Cd}$ & $\mathrm{mg} / \mathrm{L}$ & $<0.005$ & $<0.005$ & $<0.005$ & $<0.005$ & $<0.005$ & $<0.005$ & $<0.005$ & 0.003 & 0.01 \\
\hline $\mathrm{Cr}$ & $\mathrm{mg} / \mathrm{L}$ & $<0.01$ & $<0.01$ & $<0.01$ & $<0.05$ & $<0.05$ & $<0.05$ & $<0.05$ & 0.05 & 0.1 \\
\hline $\mathrm{Cu}$ & $\mathrm{mg} / \mathrm{L}$ & $<0.01$ & $<0.01$ & $<0.01$ & $<0.02$ & $<0.02$ & $<0.02$ & $<0.02$ & 1 & 0.2 \\
\hline $\mathrm{Fe}$ & $\mathrm{mg} / \mathrm{L}$ & 0.06 & 0.47 & 0.1 & 0.04 & 0.1 & 0.1 & 0.54 & 1 & 5 \\
\hline $\mathrm{Mn}$ & $\mathrm{mg} / \mathrm{L}$ & $<0.01$ & $<0.01$ & $<0.01$ & $<0.01$ & $<0.017$ & $<0.017$ & $\cdots$ & 0.1 & 0.2 \\
\hline $\mathrm{Pb}$ & $\mathrm{mg} / \mathrm{L}$ & $<0.01$ & $<0.01$ & $<0.01$ & $<0.09$ & $<0.09$ & $<0.09$ & $<0.09$ & 0.01 & 5 \\
\hline $\mathrm{Ni}$ & $\mathrm{mg} / \mathrm{L}$ & $<0.01$ & $<0.01$ & $<0.01$ & $<0.04$ & $<0.04$ & $<0.04$ & $<0.04$ & 0.07 & 0.2 \\
\hline $\mathrm{Zn}$ & $\mathrm{mg} / \mathrm{L}$ & $<0.017$ & 0.07 & 0.03 & 0.03 & 0.02 & 0.02 & 0.58 & 4 & 2 \\
\hline $\mathrm{TCC}$ & $\begin{array}{c}\mathrm{MPN} / 10 \\
0 \mathrm{~mL}\end{array}$ & $\begin{array}{c}<1.80 \mathrm{E}+ \\
00\end{array}$ & $\begin{array}{c}<1.80 \mathrm{E}+ \\
00\end{array}$ & $\begin{array}{c}<1.80 \mathrm{E}+ \\
00\end{array}$ & $<1.8 \mathrm{E}+0$ & $<1.8 \mathrm{E}+0$ & $\begin{array}{c}<1.8 \mathrm{E}+ \\
0\end{array}$ & $\begin{array}{c}<1.8 \mathrm{E}+ \\
0\end{array}$ & $<1.1$ & $\ldots$ \\
\hline E. coli $*$ & $\begin{array}{c}\mathrm{MPN} / 10 \\
0 \mathrm{~mL}\end{array}$ & $\begin{array}{c}<1.80 \mathrm{E}+ \\
00\end{array}$ & $\begin{array}{c}<1.80 \mathrm{E}+ \\
00\end{array}$ & $\begin{array}{c}<1.80 \mathrm{E}+ \\
00\end{array}$ & $<1.8 \mathrm{E}+0$ & $<1.8 \mathrm{E}+0$ & $\begin{array}{c}<1.8 \mathrm{E}+ \\
0\end{array}$ & $\begin{array}{c}<1.8 \mathrm{E}+ \\
0\end{array}$ & $\ldots \ldots$ & $\ldots$ \\
\hline
\end{tabular}


Table 2. Types of liquid wastes disposed from June 2010-October 2010

\begin{tabular}{lcc}
\hline Type of Liquid Waste & Quantity $(\mathrm{kg})$ & Quantity (m3) \\
\hline Clothes & 1598180 & 1566.84 \\
Paper Bags & 479700 & 470.29 \\
Private and Unknown & 837240 & 820.82 \\
Chicken Liquid Waste & 952420 & 933.75 \\
Liquid-Treatment plant Sludge & 20590950 & 20187.21 \\
Olive (Zibar) & 3993880 & 3915.57 \\
Kamkha & 9733420 & 9542.57 \\
Yoghurt & 510460 & 500.45 \\
Slaughter house & 1217640 & 1193.76 \\
Total & 39913890 & 39131.26 \\
\hline
\end{tabular}

\section{Conclusions and Recommendations}

The assessment of the potential impacts on the contamination of groundwater resources require review and validation of the current hydrogeological data and previous reports and studies conducted at ADS. Al-Ekeder landfill is located in an area marked by high protective effectiveness of the of the Muwaqqar formation $\left(B_{3}\right)$ which overlays the $A_{7} / B_{2}$ Aquifer System in normal geological conditions. The research concludes the followings:

(1) Due to presence of several structural elements related to the Jordan Rift Valley, this situation did not last for long as the contamination observed in western wells.

(2) The water contamination is candidate to further rapid increase leading to serious pollution of $A_{7} / B_{2}$ Aquifer System.

(3) The observed contamination took long time (20-30 years) due to the slow process of infiltration of the pollutants through the underlaying unsaturated chalk limestone strata.

(4) Hence, $B_{3}$ Formation of the underlaying chalk limestone strata become highly saturated, the contamination stared to appear in the groundwater of the aquifer system and will increase unless further precaution is taken.

Therefore, it is recommended to conduct a periodic monitoring (every two or three months) of the western wells that have showed signs of pollution. The measurements should include recording of water level, sampling, testing and analysis of the results of the water quality and direction of water movement under the disposal site and in the surrounding area.

\section{References}

Abu-Qdais, H., Abdulla, F., \& Qrenawi, L. (2009). Solid waste landfill as source of green energy: case study of Al-Akeeder landfill. International Conference and Exhibition on Green Energy and Suitability for Arid Regions and Mediterranean countries (ICEGES).

Abu-Rukah, Y., \& Abu-Aljarayesh, I. (2002). Thermodynamics assessment in heavy metal migration at El-Akader landfill site, North Jordan. Waste Management Journal, 22, 707-723. http://dx.doi.org/10.1016/S0956-053X(02)00046-6

Abu-Rukah, Y., \& Al-Kofahi, O. (2001). The assessment of the effect of landfill leachate on groundwater quality: Case study of El-Akader landfill site, North Jordan. Journal of Arid Environment, 49, 615-630. http://dx.doi.org/10.1006/jare.2001.0796

Abu-Rukah,Y., \& El-Aloosy, A. S. (1997). Various variables migration in landfill site, using statistical explanation: A case study El-Akader landfill site, North Jordan. Journal of the Institute of Mathematics and Computer Sciences, 10(2), 113-130.

American Public Health Association, American Water Works Association, \& Water Environment Federation. (2005). Standard Methods for the Examination of Water and Wastewater (20th ed.). American Public Health Association, American Water Works Association, Water Environment Federation, USA. 
Awawdeh M., \& Jaradat, R. A. (2009). Evaluation of aquifers vulnerability to contamination in the Yarmouk River Basin, Jordan, based on DRASTIC method. Arab Journal of Geosciences, 3(3), 273-282. http://dx.doi.org/10.1007/s12517-009-0074-9

Ball, J. M., \& Novella, P. H. (2003). Coastal Park Landfill: leachate plume migration and attenuation. In T. H. Christensen, R. Cossu, \& R. Stegmann (Eds.), Proceedings Sardinia 2003, Ninth International Landfill Symposium. CISA Publisher.

Bender, F. (1968). Geologie von Jordanien-Beitraege zur regionalen Geologie; Region. D. Erde 7 (p. 230). Berlin, Stuttgart: Gebrueder Borntraeger.

Bender, F. (1974). Geology of Jordan, Supplementary edition in English with minor revisions, Beiter Region. Geol. Erde (Suppl. 7, p. 196). Berlin: Gebrueder Borntraeger.

BGR-Bundesanstalt fuer Geowissenschaften und Rohstoffe and WAJ-Water Authority of Jordan. (1994). Groundwater Resources of Northern Jordan, Vol. 3, Structural Features of the Main Hydrogeological Units in Northern Jordan. Unpubl. Report, Water Authority of Jordan (WAJ), Amman-Jordan.

BGR-Bundesanstalt fuer Geowissenschaften und Rohstoffe. (1987). Geophysical Investigations for Groundwater Resources in Azraq Basin. Unpublished report submitted for the Ministry of Water and Irrigation. Amman-Jordan.

El-Naser, H. (1991). Groundwater resources of deep aquifer system in NW-Jordan: hydrogeological and hydrogeochemical quasi 3-dimensional modelling ( $\mathrm{PhD}$ thesis, Uni. Würzburg, Würzburg, p. 144).

Futta, D., Yoscos, C., Haralambous, K. J., \& Loizidou, M. (1997). Assessment of the effect of landfill leachate on groundwater. Proceeding Sardinia 97, Sixth International Landfill Symposium, Cagliari, Italy, 13-17 Oct: : 181-187.

Jordan Standards (JS-286). (2001). Jordanian Standards for drinking water. Ministry of Water and Irrigation. Amman, Jordan.

Khoury, H. N., \& Salameh, E. (1985). Leaching of Ruseifa phosphates and Maqarin bituminous limestone and its effect on the quality of groundwater. Dirasat, 12, 81-99

MacDonald, Sir, M., \& Partners in Cooperation with Hunting Technical Services Limited. (1966). Wadi Dhuleil Irrigation Project: Hydrogeology-Central Water Authority, Amman.

Margaene, A., Hobler, M., \& Subah, A. (1999). Mapping of Groundwater Vulnerability and Hazards to Groundwater in the Irbid Area, N. Jordan. Federal Institute for Geosciences and Natural Resources (BGR). Z. Angew. Geol., 45, 4.

Ministry of Environment. (2006). Al-Ekeder industrial wastewater management assessment. Draft final report.

Olivero-Verbel, J., Padilla-Bottet, C., \& LaRosa, O. D. (2008). Relationship between physiochemical parameters and toxicity of leachates from municipal solid waste landfill. Ecotoxicology and Environmental Safety, 70, 294-299. http://dx.doi.org/10.1016/j.ecoenv.2007.05.016

Rajkumar, N., Subramani, T., \& Elango, L. (2012). Impact of leachate on groundwater pollution due to non-engineered municipal solid waste landfill sites of erode city, Tamil Nadu, India. Iranian Journal of Environmental Health Science \& Engineering, 9, 35. http://dx.doi.org/10.1186/1735-2746-9-35

Rimawi, O. (1992). Salinization and water quality of the groundwater resources in Dhuleil-Hallabat area- Jordan. Dirasat, 19B(3), 131-176. Amman, Jordan: University of Jordan.

Salameh, E. (1996). Water Quality Degradation in Jordan, Impacts on Environment, Economy and Future Generations. Final Report Friedrich-Ebert-Stiftung \& Royal Society for the Conservation of Nature. National Library, Deposit No. 1134/8/1996; Amman.

Sawarieh, A., \& Massarweh, R. (1997). Geothermal Water in Mukhiebeh and North Shuna areas, Geothermal Energy Project, Internal report No. 9 (p. 25). Amman, Jordan: Natural Resources Authority.

The Royal Scientific Society (RSS). (2006). Annual Analysis Report.

UNDP/FAO. (1970). Investigation of the Sandstone Aquifer of East Jordan. U. N. Devp. Prog./Food and Agric. Org., AGL SF/Jor. 9, Rome (p. 286).

Water Authority of Jordan \& Bundesanstalt fuer Geowissenschaften und Rohstoffe (WAJ/BGR). (1997). Groundwater Resources of Northern Jordan, Vol. 3, Structural Features of the Main Hydrogeological Units in Northern Jordan. Unpubl. Report, Water Authority of Jordan (WAJ), Amman-Jordan. 


\section{Copyrights}

Copyright for this article is retained by the author(s), with first publication rights granted to the journal.

This is an open-access article distributed under the terms and conditions of the Creative Commons Attribution license (http://creativecommons.org/licenses/by/3.0/). 